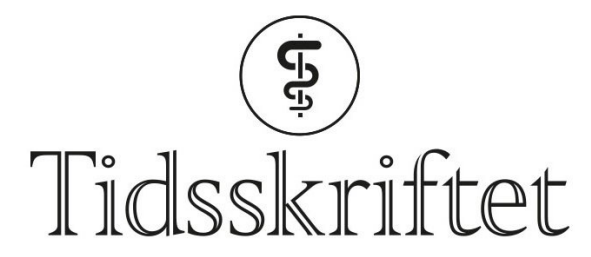

DEN NORSKE LEGEFORENING

\title{
Sprechen Sie Statistik?
}

MEDISIN OG TALL

\section{KATHRINE FREY FRØSLIE}

E-post: kathrine.frey.froslie@nmbu.no

Kathrine Frey Frøslie er førsteamanuensis i biostatistikk ved Norges miljø- og biovitenskapelige universitet og driver den populærvitenskapelige strikkebloggen statistrikk.no.

Forfatter har fylt ut ICMJE-skjemaet og oppgir ingen interessekonflikter.

\section{JO RØISLIEN}

Jo Røislien er professor i medisinsk statistikk ved Det helsevitenskapelige fakultet, Universitetet i Stavanger, og en profilert fagformidler og programleder på TV.

Forfatter har fylt ut ICMJE-skjemaet og oppgir ingen interessekonflikter.

Er statistikk et fremmedspråk, på linje med tysk, latin eller mandarin?

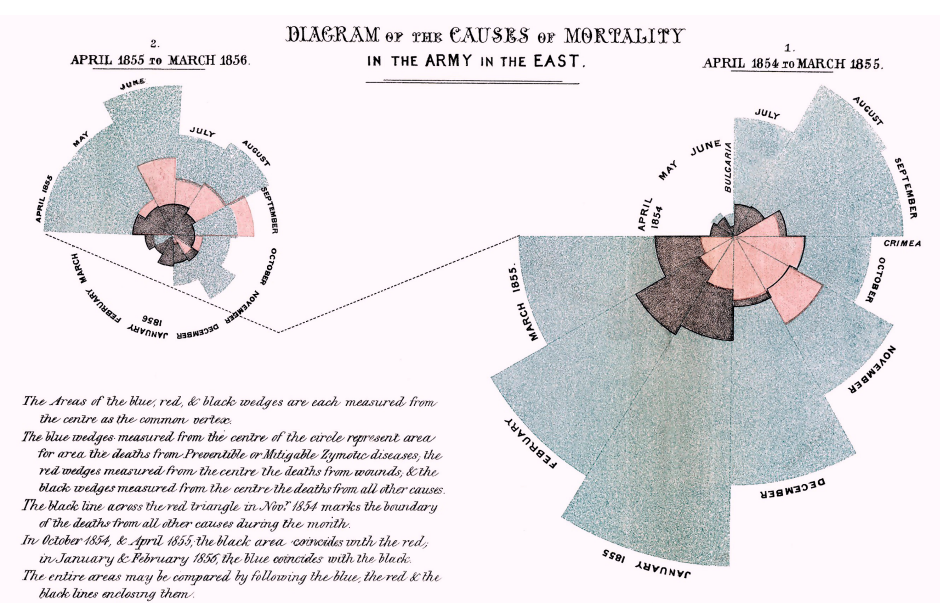

Figur 1 Florence Nightingale endret det britiske helsevesenet ved a fortelle tallhistorier om de mange. Illustrasjon: Florence Nightingale / Wikimedia Commons

Historiefortelling med tall er en hjørnestein i medisinsk forskning. Kliniske forskere oversetter egne og kollegers observasjoner av blod, sukker, svette og tårer til tall og kategorier som så kan analyseres med statistiske metoder. Erfaringer, empiri og resultater utveksles med andre fagfeller via tabeller og figurer og statistiske analyser i vitenskapelige artikler, på konferanser og i lærebøker.

Men selv om statistikk står sentralt i medisinsk kunnskapservervelse og formidling, er det få klinikere som har statistikk som sitt primære interessefelt. Tallene og analysene kan fort fremstå som fremmede, formulert i et annet språk enn det deres egen fagutdanning opererer med. Klinikere som vil forske skal prestere og kommunisere på internasjonalt toppnivå - på et språk som ikke er deres eget. 


\section{Statistikk som språk}

Et språk er et verktøy for å kommunisere tanker, ideer og kunnskap. Det er statistikk også. Både språk og statistikk har en teknisk grammatikk. Mens språklærere forteller om setningsledd og kasuser, forteller statistikkursene om standardavvik, p-verdier og regresjonskoeffisienter. Både språk og statistikk har sine alfabeter og sin tegnsetting. Der språkene bruker bokstaver og tegn, er statistikk bygd på matematisk notasjon, med matematiske formler for gjennomsnitt, standardavvik og regresjonsligninger.

For å beherske et språk må du opparbeide deg en forståelse av en rekke begreper. Så også med statistikk. Et substantiv er et ord for en ting. Et standardavvik er et tall for variasjon. Subjektet i en setning er den som gjør noe. Og oddsen er sannsynligheten for at noe skjer delt på sannsynligheten for at det ikke skjer.

For både språk og statistikk er konteksten viktig. Kunnskap om verseføtter og rim er for de fleste lite relevant - eller interessant - før kunnskapen settes i kontekst av et spesifikt dikt der forfatteren bruker virkemidlene til å løfte frem budskapet om for eksempel sorgen ved å miste et barn. Kunnskap om hvordan dataprogrammet SPSS brukes til å beregne en regresjonskoeffisient har liten klinisk relevans før det settes i kontekst av et spesifikt forskningsprosjekt og brukes til å si at risikoen for dødfødsel øker etter svangerskapets 42. uke.

Både språk og statistikk kan brukes til å fortelle viktige historier om verdenen vi lever i. Med ord kan språket dra leseren inn i fortellingen om det kjente og det ukjente og formidle følelser og forståelse. På samme måte kan tall oppsummere en samling enkeltstående pasienthistorier så godt at den kliniske innsikten fremstår som selvsagt.

\section{Statistikk som ikke-språk}

Men selv om statistikk kan ligne et språk, er det likevel ikke et fullverdig språk. Et språk har subjekter som gjør noe, verbaler for handling, det har adjektiver og superlativer. Dette mangler statistikk. Man kan ikke si "Jeg gleder meg veldig til sommerferien!» på statistiksk.

Statistikk er et spesialverktøy for å kommunisere en helt spesiell type informasjon: Kvantitativ informasjon. Statistikk er bygd på matematikk, og både utregningene og språket som beskriver metodene og tallene må være presist formulert for at budskapet skal bli riktig. Matematikken kan ikke endres eller tilpasses for å oppnå kommunikasjon - både avsenderen og mottageren må lære seg matematikken. Det er annerledes enn hvordan all annen språklig kommunikasjon fungerer.

På ethvert språk vil du kunne bli forstått selv om du bruker feil ord og det er store grammatikalske mangler i det du sier eller skriver. Om du sier «besta» eller "momo», så skjønner vi hvem du snakker om, selv om ingen av ordene står i noen ordbok. Om du blander «og» og «å» eller «fullt» og «fult» i en SMS, vil god kommunikasjon like fullt kunne oppnås. Slik er det ikke med statistikk. Bruker du feil ord, velger feil tall for å oppsummere dataene dine eller presenterer feil statistisk analyse, vil ikke bare kommunikasjonen halte hele forskningsprosjektet ditt vil kunne dø.

\section{Fortellingen om de mange}

Enkelthistorier fra den kliniske hverdagen kan være gripende. De handler om blødninger, spiseforstyrrelser, bivirkninger og død. Enkelthistoriene er mange, men de er fortsatt bare enkelthistorier. For å lage best mulig helsetjenester for flest mulig holder det ikke å fortelle historier om den enkelte. Vi må fortelle historien om de mange. Og denne fortelles med statistikk.

Statistikk er bygd på ufravikelige absolutter og rett og galt. Men statistikk er ikke bare matematikk. Statistikk handler om å kommunisere hva de innsamlede tallene fra et forskningsprosjekt forteller om den kliniske hverdagen. For å forstå historiene som fortelles om de mange, for selv å bli forstått når du skal videreformidle egne erfaringer, empiri og 
resultater, må du beherske språket om de mange. Du må kunne statistiksk.

Publisert: 26. februar 2019. Tidsskr Nor Legeforen. DOI: 10.4045/tidsskr.18.0887

(C) Tidsskrift for Den norske legeforening 2020. Lastet ned fra tidsskriftet.no 